\title{
Detrimental Cr-rich Phases Precipitation on SAF 2205 Duplex Stainless Steels Welds After Heat Treatment
}

\author{
Argelia Fabiola Miranda Pérez ${ }^{1}$, Marco Breda ${ }^{2}$, Irene Calliari², Gladys Yerania Pérez Medina ${ }^{1}$, Rolf Sandström ${ }^{3}$ \\ 1 Corporación Mexicana de Investigación en Materiales - COMIMSA, Saltillo, Coahuila, México. \\ 2 University of Padua, Industrial Engineering Department - DII, Padua, Italy. \\ 3 KTH Royal Institute of Technology, Department of Materials Science and Engineering, Stockholm, Sweden.
}

Received: 24 Jan., 2016

Accepted: 04 Apr., 2016

E-mails: argelia.miranda@comimsa.com (AFMP), irene.calliari@unipd.it (IC), rsand@kth.se (RS)
This is an Open Access article distributed under the terms of the Creative Commons Attribution Non-Commercial License which permits unrestricted non-commercial use, distribution and reproduction in any medium provided the original work is properly cited.

\begin{abstract}
The austeno-ferritic Stainless Steels are commonly employed in various applications requiring structural performances with enhanced corrosion resistance. Their characteristics can be worsened if the material is exposed to thermal cycles, since the high-temperature decomposition of ferrite causes the formation of detrimental secondary phases. The Submerged Arc Welding (SAW) process is currently adopted for joining DSS owing to its relatively simple execution, cost savings, and using molten slag and granular flux from protecting the seam of atmospheric gases. However, since it produces high contents of $\delta$-ferrite in the heat affected zone and low content of $\gamma$-austenite in the weld, high-Ni filler materials must be employed, to avoid excessive ferritization of the joint. The present work is aimed to study the effect of 3 and 6 hours isothermal heat treatments at $850^{\circ} \mathrm{C}$ and $900^{\circ} \mathrm{C}$ in a SAF 2205 DSS welded joint in terms of phases precipitation. The results showed the presence of $\sigma$-phase at any time-temperature combination, precipitating at the $\delta / \gamma$ interphases and often accompanied by the presence of $\chi$-phase. However, certain differences in secondary phases amounts were revealed among the different zones constituting the joint, ascribable both to peculiar elements partitioning and to the different morphology pertaining to each microstructure.
\end{abstract}

Key-words: Duplex Stainless Steels; SAW; Heat treatment; Sigma; Chi.

\section{Precipitação de Fases Prejudiciais Ricas em Cromo em Soldas de Aço Inoxidável Duplex SAF 2205 Após Tratamento Térmico}

Resumo: Os Aços Inoxidáveis austeno-ferriticos são comumente utilizados em diversas aplicações que requerem desempenho estrutural, maior resistência à corrosão. As suas características podem ser prejudicadas se o material for exposto a ciclos térmicos, uma vez que a decomposição a alta temperatura da ferrita provoca a formação de fases secundárias prejudiciais. O processo de soldagem a arco submerso (SAW) é atualmente adotado para unir DSS devido à sua execução relativamente simples, economia de custos, e utiliza escória fundida e fluxo granular para proteger a costura dos gases atmosféricos. No entanto, uma vez que são produzidos elevados teores de ferrita- $\delta$ na zona afetada pelo calor e baixo teor de austenita- $\gamma$ na solda, materiais de adição de alto-Ni devem ser empregados, de modo a evitar excessiva ferritização na junta. O presente trabalho tem como objetivo estudar o efeito de 3 e 6 horas de tratamentos térmicos isotérmicos a $850^{\circ} \mathrm{C} \mathrm{e} 900^{\circ} \mathrm{C}$ em uma junta soldada de DSS SAF 2205 em termos de precipitação de fases. Os resultados mostraram a presença de fase- $\sigma$ em qualquer combinação de tempo-temperatura, precipitando nas interfases $\delta / \gamma$ e muitas vezes acompanhada pela presença de fase- $\chi$. No entanto, algumas diferenças na quantidade de fases secundárias foram reveladas nas diferentes zonas que constituem a junta, ambas atribuídas aos elementos peculiares de partição e à morfologia diferente pertencente a cada microestrutura.

Palavras-chave: Aços inoxidáveis duplex; SAW; Tratamento térmico; Sigma; Chi.

\section{Introduction}

Duplex Stainless Steels (DSS) are characterized by an interesting combination of corrosion-resistance and mechanical properties, making them very suitable for structural applications in petrochemical, pharmaceutics and nuclear industries, as well as in off-shore and marine environments. DSS are biphasic steels possessing a 50/50 balanced microstructure composed by almost equal volume fraction of ferrite $(\delta)$ and austenite $(\gamma)$; for this reason, DSS exhibit a partially ferromagnetic behavior together with a good thermal 
conductivity and have a lower thermal expansion coefficient than austenitic steels. Further, the duplex structure assures considerably high strength levels at elevated temperature, good toughness and ductility [1-10].

Nevertheless, the ferritic matrix suffers from a decomposition process during isothermal aging within a critical temperature range, located at $650-950^{\circ} \mathrm{C}$, which can cause the precipitation of harmful secondary phases, such as $\sigma$-phase, $\chi$-phase, carbides and nitrides. These phases are known to be deleterious for the corrosion resistance of DSS, since all of them are considerably enriched in chromium [7-10]. Moreover, these phases represent a solution of continuity in the biphasic structure, acting as preferential sites for crack initiation and, therefore, causing a worsening of the mechanical properties. For this reason, after the hot-working processes, DSS are subjected to a solution-annealing treatment (solubilization) at $1050-1100^{\circ} \mathrm{C}$, aimed to restore the balanced (duplex) microstructure and to re-dissolve the eventually formed secondary phases.

In the fabrication of components or equipment, manufacturers frequently employ welding as the principal joining method, which may be followed by an isothermal heat treatment. Such a manufacturing process produces changes in the microstructure that modifies the desired properties. Therefore, since thermal cycles performed within the DSS critical temperature range can cause the precipitation of secondary phases, especial care must be taken during the welding operations. DSS can be joined by all arc welding processes, in which Shielded Metal Arc Welding, Gas Tungsten Arc Welding, Gas Metal Arc Welding and Submerged Arc Welding (SAW) are the most employed. SAW process was developed nearly the 1940 and is well-adapted since then. Their benefits include a molten slag which protects the seam weld from atmospheric contamination, high productivity and high welding quality [11,12]. Is commonly used for joining DSS and previous studies have evidenced that a proper setting of processing parameters in welding the 2205 DSS grade has resulted in a satisfactory $\delta-\gamma$ phase balance in the heat-affected-zone [7-9,13].

However, the microstructure developed after welding is different from that resulting after hot-working in terms of phases morphology and elements partitioning, affecting both the properties of the joint and the precipitation behavior during heat treatments. J. Lou et al. applied in 2205 DSS welds a post weld heat treatment in which their observations conducted to evidence some changes of second phases, segregation and element diffusion improving the microstructure of the heat affected zone (HAZ) of the SAW joints. However, these segregations produced a reduction of the mechanical properties and performance in the DSS joints [14].

Several studies has been performed on phases precipitation in DSS [1-10], most of them concerning the solution heat-treated materials, which have permitted to define the critical temperature range for phases formation and the related loss in properties from the analysis of the Time-Temperature-Precipitation (TTP) curves. In the 2205 grade, the most common secondary phases are the intermetallics $\sigma$ - and $\chi$-phase, whereas carbides and nitrides are less frequent and only visible at very high magnification. In the present paper, the effects of isothermal aging at $850^{\circ} \mathrm{C}$ and $900^{\circ} \mathrm{C}$ on the microstructure of a welded SAF 2205 DSS are discussed, focusing on the different behavior of the welded metal respect to the base material after long time treatments ( 3 and 6 hours).

\section{Experimental}

The base material was a SAF 2205 DSS, received as plate of $30 \mathrm{~mm}$ in thickness and having the composition reported in Table 1. Plates were welded together to form butt joints along the longitudinal direction by adopting the SAW process and employing the ER 2209 as filler metal (composition in Table 1), which contains a higher percentage of $\mathrm{Ni}$ respect to the base material in order to counteract an excessive ferritization of the joint.

The isothermal ageing treatments of specimens - previously solubilized at $1050^{\circ} \mathrm{C}$ - were carried at $850^{\circ} \mathrm{C}$ and $900^{\circ} \mathrm{C}$ for 3 and 6 hours and were followed by water quenching. The metallographic sections were prepared for optical (OM) and electron (SEM) microscopy by using standard polishing techniques; for OM observations, the

Table 1. Chemical compositions of base and filler materials, Fe bal. (wt.\%).

\begin{tabular}{lccccccc}
\hline & $\mathbf{C}$ & $\mathbf{C r}$ & $\mathbf{N i}$ & Mo & Mn & Si & N \\
SAF 2205 & 0.019 & 21.9 & 5.7 & 3.0 & 1.5 & 0.5 & 0.16 \\
EN 2209 & 0.020 & 22.5 & 9.0 & 3.0 & 1.2 & 0.7 & 0.15 \\
\hline
\end{tabular}


specimens were etched using Murakami solution ( $30 \mathrm{~g} \mathrm{KOH}, 30 \mathrm{~g} \mathrm{~K}_{3} \mathrm{Fe}(\mathrm{CN}) 6$ and $60 \mathrm{ml} \mathrm{H}_{2} \mathrm{O}$ ), whereas the SEM investigation was performed on unetched samples.

The volume fraction of the phases was measured by image analysis on the OM and SEM micrographs and the chemical composition of the phases was determined using a Falcon FEl energy dispersive X-ray spectrometer (EDS) attached on SEM; the collected EDS data were quantified using a ZAF correction method on a Quantax software.

\section{Results and Discussion}

The as-received Base Material (BM) consisted of a ferrite matrix containing elongated $\gamma$-grains that were approximately estimated to be the $51 \%$ of the total volume fraction (Figure 1a), thus denoting a well-balanced structure. Conversely, the solidification microstructure in the Fusion Zone (FZ) was composed by a lower amount of $\gamma$-phase respect to $\mathrm{BM}$, either in form of dendrites or restructured as Widmanstätten plates, constituting about the $35 \%$ of the duplex structure (Figure 1b). In FZ, the observed unbalanced phase ratio was due to the rapid solidification process of the welding joint, which primarily solidified as fully ferritic, whereas austenite was subsequently formed during cooling to room temperature.
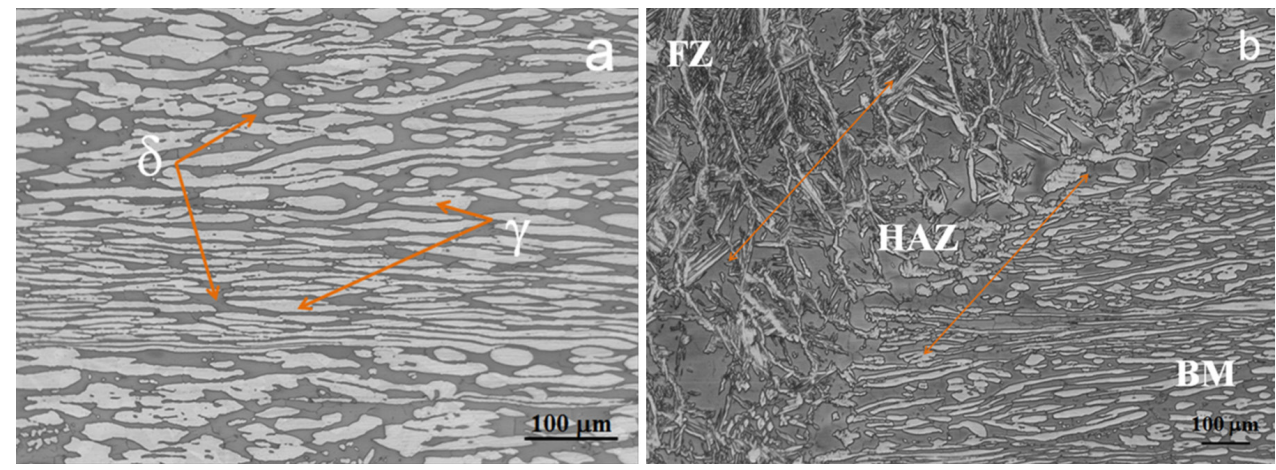

Figure 1. Optical Microscope images of (a) the base material SAF 2205 as-received and (b) FZ/HAZ/BM interfaces.

On the other hand, the Heat Affected Zone (HAZ) adjacent to the fusion line (Figure 1b) presented a further lower amount of $\gamma$-phase if compared to the other zones, where the austenite morphology was altered by the thermal supply due to the SAW process. As expected, the average grain size in FZ and HAZ were increased respect to $\mathrm{BM}$, as a consequence of the high heat input.

Beside the morphological differences, BM- and FZ-phases exhibited different compositions (Table 2), owing to the different thermal histories at which were subjected; indeed, BM was solution-annealed at about $1050^{\circ} \mathrm{C}$ and then water quenched, while FZ directly derived from cooling the melt. It is well known that solubilization is aimed to obtain partitioning coefficients pointing toward unity, but the usually adopted temperature range $\left(1050-1100^{\circ} \mathrm{C}\right)$ determines a greater elements partitioning if compared to melted DSS [1], by following the affinity of each element toward $\delta$ - or $\psi$-phase. In DSS, the solution-annealing temperature is mainly chosen as a function of the alloying elements content, but must be limited in order to maintain the balanced structure, and the higher the temperature the higher the risk to obtain excessive ferrite.

Table 2. EDS compositions of $\delta$-ferrite and $\gamma$-austenite measured in the base material (wt.\%).

\begin{tabular}{|c|c|c|c|c|c|c|c|}
\hline \multirow{2}{*}{ Zone } & \multirow{2}{*}{ Phase } & \multicolumn{6}{|c|}{ Composition (wt.\%) } \\
\hline & & Si & $\mathrm{Cr}$ & Mo & $\mathbf{N i}$ & $M n$ & $\mathrm{Fe}$ \\
\hline \multirow[t]{2}{*}{ BM } & $\delta$ & 0.5 & 24.5 & 4.6 & 3.7 & 1.2 & bal. \\
\hline & $\gamma$ & 0.4 & 19.0 & 2.2 & 7.2 & 1.5 & bal. \\
\hline \multirow[t]{2}{*}{ FZ } & $\delta$ & 0.5 & 22.2 & 2.9 & 7.7 & 1.3 & bal. \\
\hline & $\gamma$ & 0.5 & 21.7 & 3.3 & 8.5 & 1.4 & bal. \\
\hline
\end{tabular}


In the material under study, the BM-ferrite was found to be more enriched in $\mathrm{Cr}$ and Mo, while $\mathrm{Ni}$ and $\mathrm{Mn}$ preferentially diffused in austenite; conversely, the elements were more equally distributed within the FZ-phases, due to the reaching of the melting temperature and to the rapid solidification process that characterized the welded material (Table 2).

In 2205 DSS, the nose of the TTP curve is located at about $850^{\circ} \mathrm{C}$ and, at this temperature, the formation of intermetallics usually requires about 20 minutes of soaking time $[3,9]$. Therefore, treating the material for more than three hours is expected to cause a copious precipitation of secondary phases and the formation of an increased volume fraction of austenite respect the untreated joints, owing to the eutectoidic decomposition of ferrite $(\delta \rightarrow \sigma+\gamma 2)$, the presence of secondary austenite can be due to two mechanisms, from the existing austenite or within the ferrite associated with nitrides precipitation [15]. Neither of both mechanisms was presented in this study since $\gamma 2$ needs rapid cooling kinetic formation. BM, HAZ and FZ possessed different microstructures in terms of phase morphologies and elements partitioning and, moreover, FZ can be further split in two distinct areas - an upper (FZ-up) and a lower (FZ-down) zone - owing to heating effects caused by the backhand welding operations.

In Figure 2, the welded microstructures in FZ-up and FZ-down of the sample heat treated at $850^{\circ} \mathrm{C}$ for 3 hours are reported. In FZ-up, austenite and $\sigma$-phase were found to be the only microstructural constituents, denoting the total decomposition of ferrite in the upper part of the joint. On the contrary, the observations in FZ-down revealed that ferrite was not totally replaced by $\sigma$ and that a not negligible amount of $\chi$-phase was present. On the other hand, HAZ and BM were affected by lower amounts of secondary phases, owing to their different microstructural features respect to FZ (Figure 3).
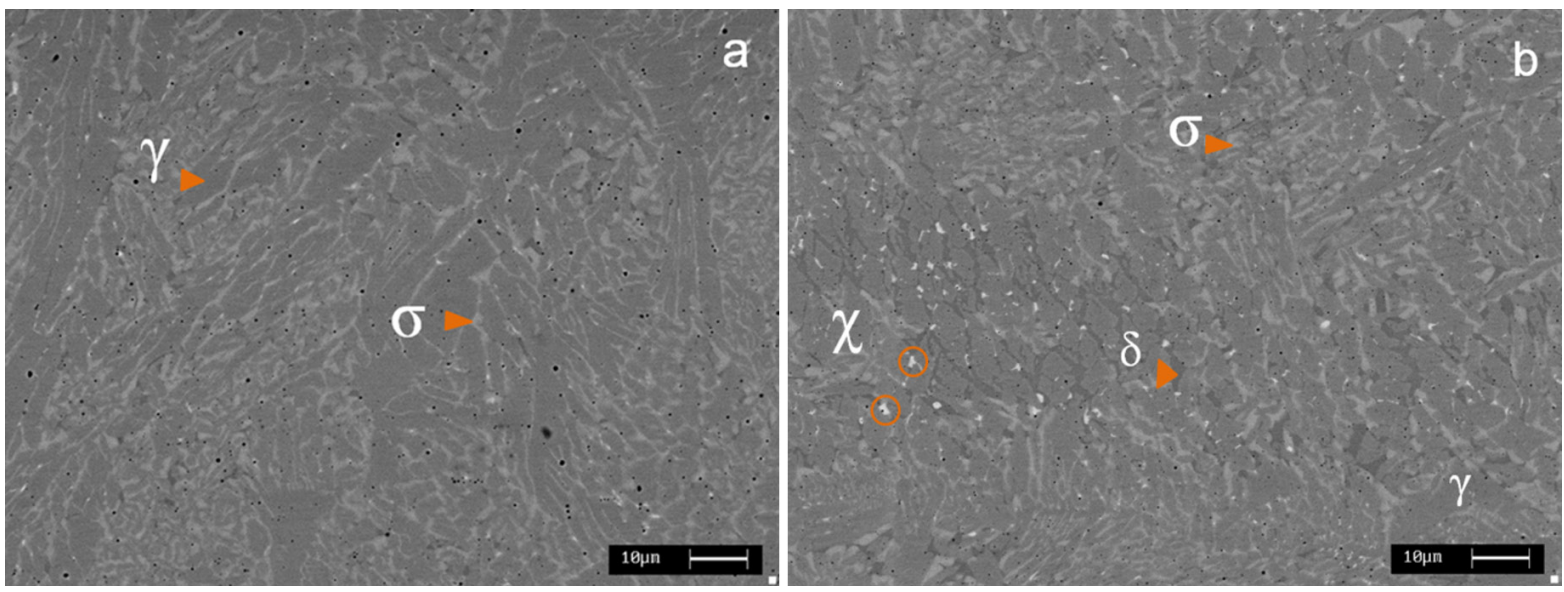

Figure 2. SEM images of the sample treated at $850^{\circ} \mathrm{C}$ for 3 hours: (a) Upper Fusion Zone and (b) Lower Fusion Zone.
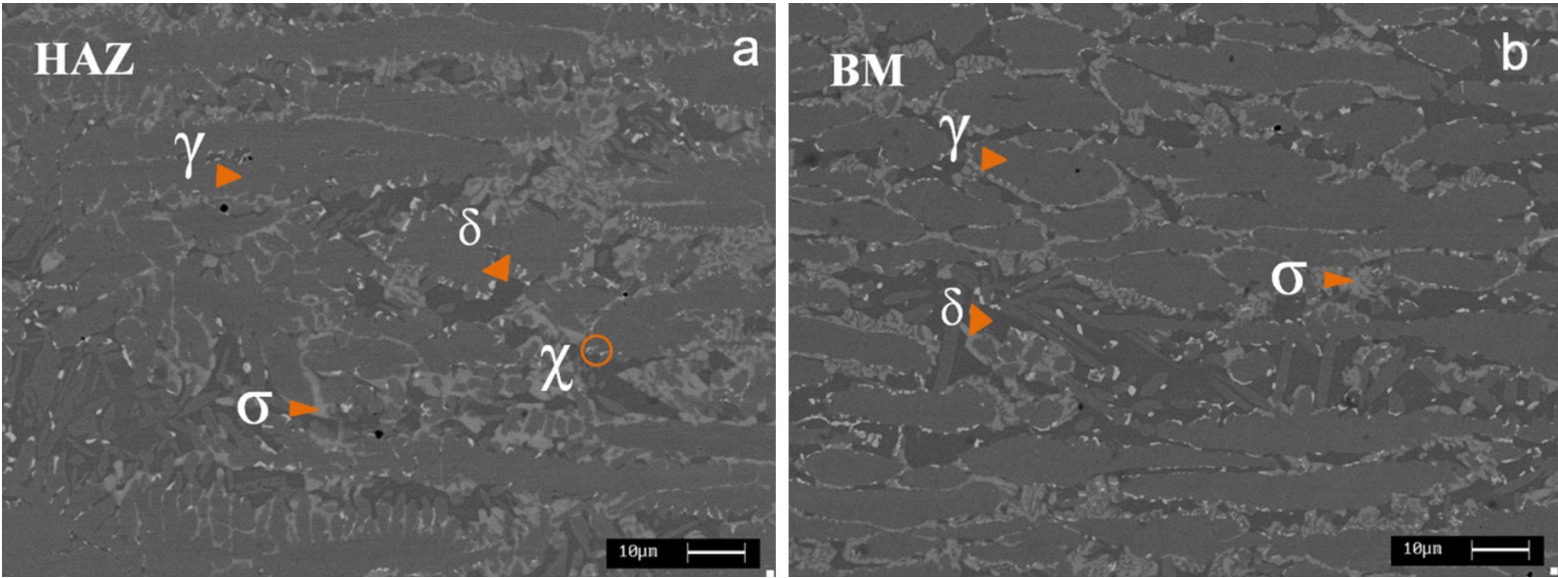

Figure 3. Scanning Electron micrographs of the sample treated at $850^{\circ} \mathrm{C}$ for 3 hours: (a) Heat Affected Zone and (b) Base Metal. 
Considering the presence of $\sigma$-phase, similar results were obtained after all isothermal treatments and, even if the estimated volume fractions were different, the same trend was revealed by passing from one zone to another (Figure 4). As expected, the performed treatments caused ferrite decomposition in all the parts of the joints, but the precipitated amounts were conditioned by the characteristic microstructures pertaining to each part.

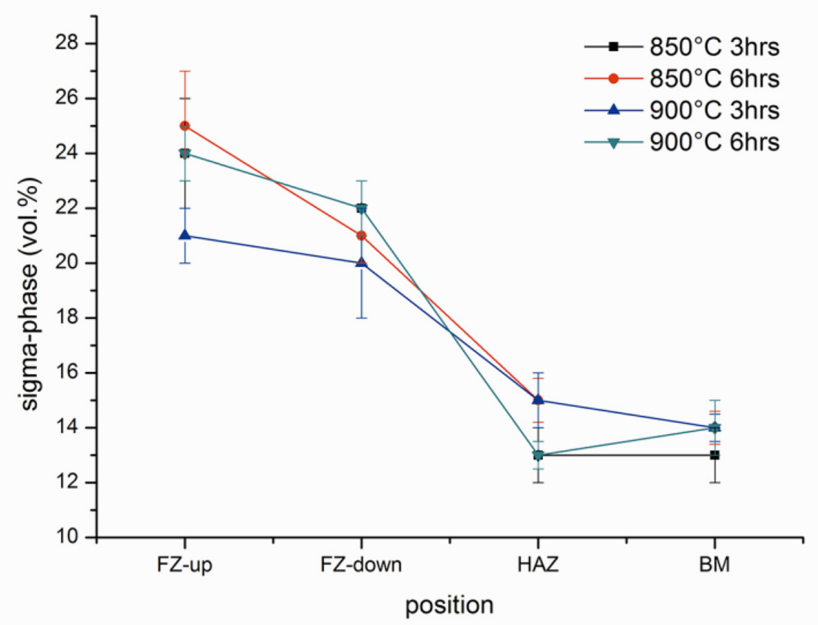

Figure 4. $\sigma$-phase amounts estimated after the heat treatments in the different joint positions.

In FZ, the development of partitioning coefficients almost equal to unity determined a greater metastability of ferrite respect to $\mathrm{HAZ}$ and $\mathrm{BM}$, making the phase more prone to secondary phases precipitation. In this zone, ferrite was in any case almost completely replaced by $\sigma$ and, further, the backhand welding caused a differentiate heating between FZ-down and FZ-up, determining a different metastable situation and resulting in different amount of phase fractions after the treatments.

On the contrary, BM and HAZ were conditioned by other thermal cycles if compared to FZ - solubilization and heating on welding, respectively - which caused a reduced precipitation of $\sigma$-phase, owing to a greater elements partitioning between the two duplex phases that lowered the driving force for $\sigma$-phase formation.

In $\mathrm{BM}$ and $\mathrm{HAZ}$, the $\sigma$-phase morphology was found to be different at the two considered temperatures, assuming a coral-like character at $850^{\circ} \mathrm{C}$ and a bulk shape at $900^{\circ} \mathrm{C}$, as also noted by Pohl et al. [10]. In any case, $\sigma$-phase nucleated at grain boundaries and grown toward ferrite, and the observed differences in particles shape were due to diffusional/nucleation effects, which conditioned the phases morphology deriving from the eutectoid reaction, causing a greater interconnection between ferrite and $\sigma$ at lower temperatures (Figure 5). In FZ, owing to the total decomposition of ferrite and to microstructural features, these differences in shape were less evident.
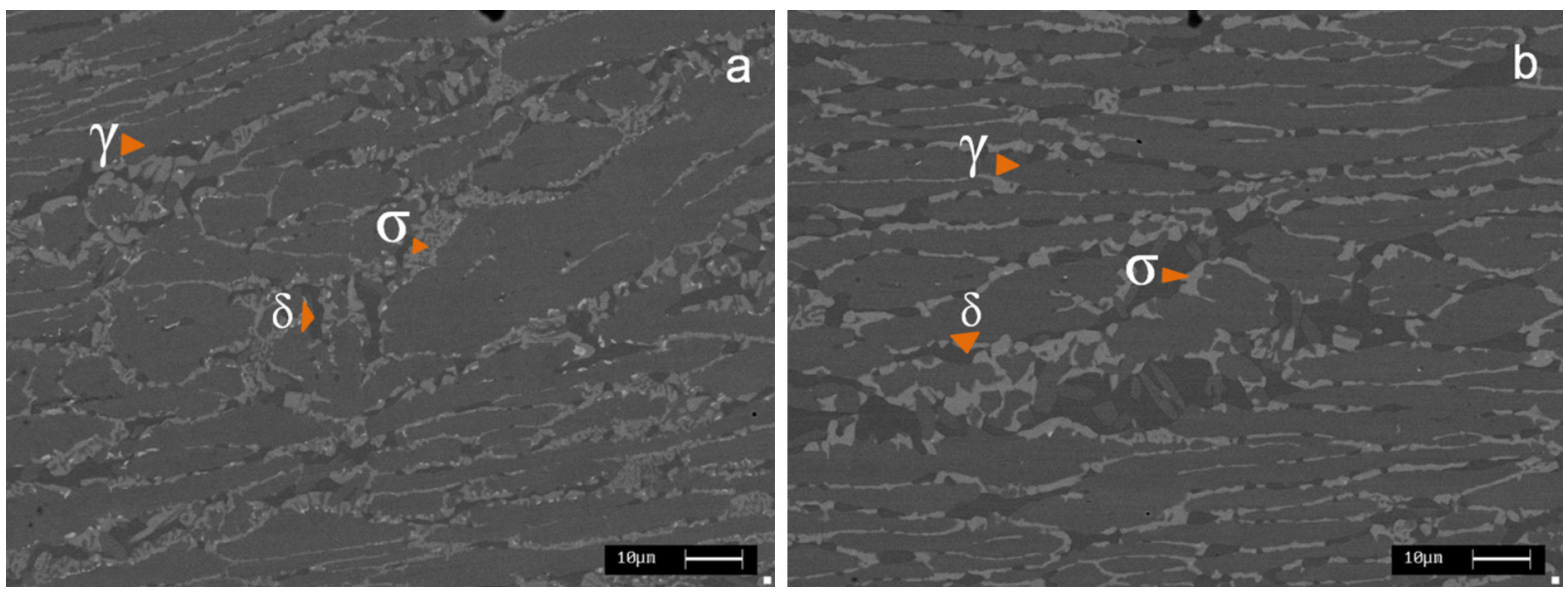

Figure 5. SEM images of the sample heat treated for 6 hours at (a) $850^{\circ} \mathrm{C}$ and (b) $900^{\circ} \mathrm{C}$. 
Even though certain regularity among the joint zones was found for $\sigma$-phase precipitation, the trends were different if the other intermetallic - the $\chi$-phase - is considered (Figure 6). This secondary phase was mainly observed after the $850^{\circ} \mathrm{C}$ treatments, since the $900^{\circ} \mathrm{C}$ temperature is toward the upper limit of the $\chi$-phase stability-field; further, this phase tend to disappear in favor of $\sigma$ after long thermal exposure, especially at higher temperatures [16]. Treating the joints at $850^{\circ} \mathrm{C}$ for three hours always caused the formation of greater amounts of $\chi$-phase, which can be considered almost constant in the different welding zones. Conversely, after six hours at $850^{\circ} \mathrm{C}$ the trend seemed to be inverted respect to $\sigma$-phase precipitation and greater volume fractions of $\chi$-phase were observed in BM rather than in FZ. This was due to the tendency of $\chi$ to be replaced by $\sigma$ after long treatment times. The differences among the joint zones can be addressed to the more proneness of FZ-ferrite to $\sigma$-phase decomposition, thus causing an anticipation of the precipitation sequence and the formation of lower amount of $\chi$-phase in FZ respect to BM owing to the anticipate reaching of equilibrium conditions. In any cases, $\chi$-phase can be observed as small bright globular particles located along the $\delta / \nu$ interfaces (Figures 2, 3 and 5 ).

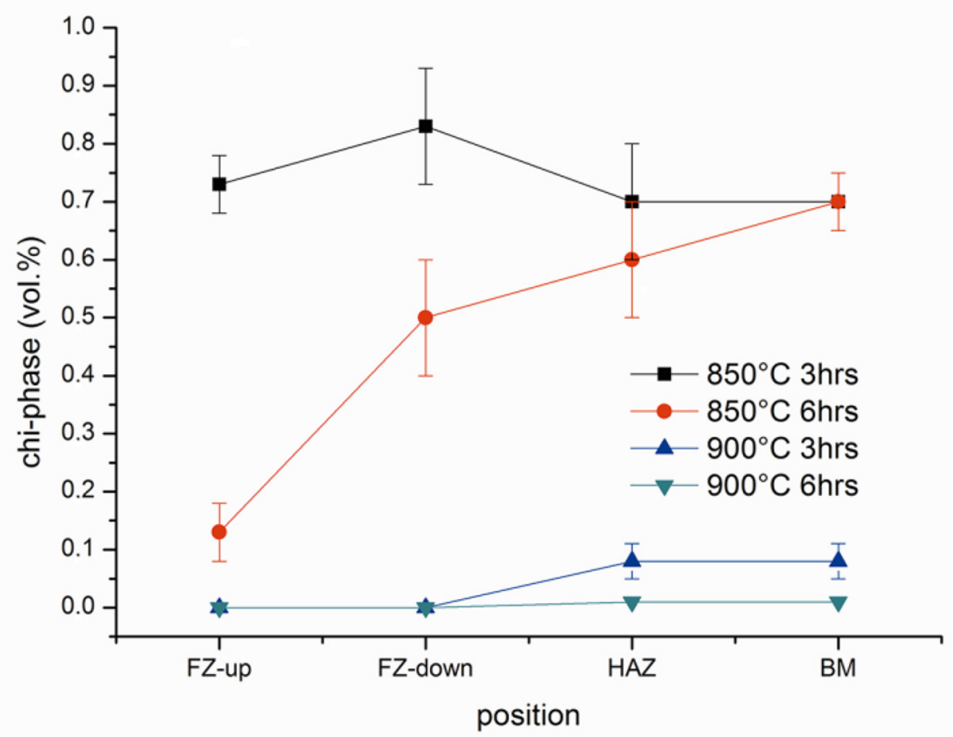

Figure 6. $\chi$-phase amounts estimated after the heat treatments in the different joint positions.

\section{Conclusions}

In the present work, the effects of 3 and 6 hours isothermal heat treatments at $850^{\circ} \mathrm{C}$ and $900^{\circ} \mathrm{C}$ on a 2205 DSS welding by SAW process were examined. As expected, the employed time-temperature combinations always caused the formation of considerable amounts of $\sigma$ - and $\chi$-phase, whose volume fractions depended on the considered part of the joint (i.e. base material, BM; heat-affected zone, HAZ; and fusion zone, FZ).

Indeed, all the parts constituting the joints where affected by ferrite decomposition, but the precipitated amounts were conditioned by the characteristic microstructures pertaining to each part. In FZ, owing to the rapid cooling from the melt, the alloying elements were almost equally partitioned within the two duplex phases, allowing for a greater driving force for $\sigma$-phase precipitation. On the contrary, HAZ and BM were less affected by $\sigma$-phase formation, since they were only subjected to thermal cycles. In these latter parts of the joint, the elements were more partitioned within the phases by following their $\delta$ - or $\psi$-character, thus determining a greater stability against ferrite decomposition.

The presence of $\chi$-phase was mainly revealed at $850^{\circ} \mathrm{C}$, since at $900^{\circ} \mathrm{C}$ this phase is not even stable; at this latter temperature, either $\sigma$-phase precipitation is more favored or $\chi$ is quickly replaced by $\sigma$ owing to higher diffusional contributions. Both the secondary phases nucleated along the $\delta / \gamma$ interfaces and, while $\sigma$-phase grown toward the ferritic matrix and possessed peculiar morphologies depending on the ageing temperature, the $\chi$-phase always precipitated at the boundaries in globular form. 


\section{References}

[1] Gunn RN. Duplex stainless steels: microstructure, properties and applications. Cambridge: Abington Publishing; 1997.

[2] Nilsson JO. Super duplex stainless steels. Materials Science and Technology. 1992;8(8):685-700. http://dx.doi.org/10.1179/ mst.1992.8.8.685.

[3] Calliari I, Zanesco M, Ramous E, Bassani P. Effects of isothermal ageing and continuous cooling after solubilization in a duplex stainless steel. Journal of Materials Engineering and Performance. 2007;16(1):109-112. http://dx.doi.org/10.1007/s11665-0069017-8.

[4] Nilsson J-O, Kangas P, Wilson A, Karlsson T. Mechanical properties, microstructural stability and kinetics of cr-phase formation in $29 \mathrm{Cr}-6 \mathrm{Ni}-2 \mathrm{Mo}-0.38 \mathrm{~N}$ superduplex stainless steel. Metallurgical and Materials Transactions. A, Physical Metallurgy and Materials Science. 2000;31A(1):35-45. http://dx.doi.org/10.1007/s11661000-0050-1.

[5] Chen TH, Weng KL, Yang JR. The effect of high-temperature exposure on the microstructural stability and toughness property in a 2205 duplex stainless steel. Materials Science and Engineering A. 2002;338(1-2):259-270. http://dx.doi. org/10.1016/S0921-5093(02)00093-X.

[6] Karlsson L, Bengtsson L, Rolander U, Pak S. The kinetics of intermetallic phase formation in duplex stainless weld metals and their influence on mechanical properties. In: Nordberg $\mathrm{H}, \mathrm{Björklund} \mathrm{J}$, editors. Proceedings of the ASS Application Stainless Steel; 1992 June 9-11; Stockholm, Sweden. Stockholm: Jernkontoret; 1992. p. 335-344. (vol. 1).

[7] Badji R, Bouabdallah M, Bacroix B, Kaloun C, Belkessa B, Maza $H$. Phase transformation and mechanical behavior in annealed 2205 duplex stainless steel welds. Materials Characterization. 2008;59(4):447-453.

[8] Sieurin H, Sandström R. Austenite reformation in the heataffected zone of duplex stainless steel 2205. Materials Science and Engineering A. 2006;418(1-2):250-256. http://dx.doi. org/10.1016/j.msea.2005.11.025.

[9] Duprez L, De Cooman BC, Akdu N. Redistribution of the substitutional elements during $\sigma$ and $\chi$ phase formation in a duplex stainless steel. Steel Research. 2001;72:311-316.

[10] Pohl M, Storz O, Glogowski T. Effect of intermetallic precipitations on the properties of duplex stainless steel. Materials Characterization. 2007;58(1):65-71. http://dx.doi. org/10.1016/j.matchar.2006.03.015.

[11] Mcpherson NA, Chi K, Baker TN. Submerged arc welding of stainless steel and the challenge from the laser welding process. Journal of Materials Processing Technology. 2003;134:174-179.

[12] Olson DL, Hellner RL, North TH, Sims JE, Sabo RS, Chaney E, et al. ASM Handbook: submerged arc welding. 9th ed. Washington: American Society for Metals; 1983. Metals Handbook, p. 114-152, vol. 6

[13] Kotecki DJ. Some pitfalls in welding of duplex stainless steels. Soldagem \& Inspeção. 2010;15(4):336-343.

[14] Luo J., Dong Y., Li L., Wang X. Microstructure of 2205 duplex stainless steel joint in submerged arc welding by post weld heat treatment. Journal of Manufacturing Processes. 2014;16:144148.

[15] Ramirez AJ, Brandi SD, Lippold JC. Secondary austenite and chromium nitride precipitation in simulated heat affected zones of duplex stainless steels. Science and Technology of Welding and Joining. 2013;9(4):301-313. http://dx.doi. org/10.1179/136217104225021715.

[16] Calliari I, Breda M, Straffelini G, Miranda Perez AF, Reyes Valdes FA. Impact toughness of isothermally treated duplex stainless steels. In: Materials Research Society. Proceedings of the International Materials Research Congress - MRS Proceedings; 2014; Cancún. Warrendale: MRS; 2014. (vol. 1616). http://dx.doi. org/10.1557/opl.2014.237. 